\title{
Peningkatan Aktivitas Dan Hasil Belajar Biologi Siswa Melalui Penggunaan Media Interaktif Berbasis ICT (Information And Communication Technology) Siswa Kelas XI IPA 3 Di SMA Negeri 1 Wonomulyo
}

\author{
Syamsiara Nur \\ Program Studi Pendidikan Biologi FMIPA Universitas Sulawesi Barat \\ E-mail : nur_syamsiara@yahoo.co.id
}

\begin{abstract}
Abstrak
Penelitian bertujuan untuk meningkatkan aktivitas dan hasil belajar siswa dengan menggunakan media interaktif berbasis ICT. Subjek penelitian ini adalah siswa kelas XI IPA 3 SMA Negeri 1 Wonomulyo semester genap tahun ajaran 2009/2010. Penelitian ini adalah penelitian tindakan kelas, terdiri atas 2 siklus, setiap siklus terdiri atas 3 kali pertemuan. Data diperoleh dengan menggunakan 3 instrumen, yaitu lembar observasi untuk aktivitas, angket untuk sikap, dan tes evaluasi untuk hasil belajar. Analisis data dilakukan secara deskriptif dan inferensial. Hasil penelitian menunjukkan dari siklus I ke siklus II, yaitu rata-rata nilai hasil belajar siswa meningkat dari 68,81 menjadi 74,93, sedangkan peningkatan persentase siswa yang tuntas dari 70,37\% menjadi 96,30\%. Selain nilai hasil belajar siswa yang meningkat, aktivitas dan sikap siswa juga meningkat. Peningkatan aktivitas tersebut meliputi, (1) mengamati media interaktif berbasis ICT, (2) menyimak penjelasan guru, (3) mencatat penjelasan guru, (4) mengerjakan soal berbasis flash, (5) aktif menjawab pertanyaan. Berdasarkan hasil penelitian, disimpulkan bahwa penggunaan media interaktif berbasis ICT dapat meningkatkan aktivitas dan hasil belajar siswa, serta dari perhitungan regresi dan korelasi diketahui terdapat hubungan positif antara aktifitas dan sikap terhadap hasil belajar siswa.
\end{abstract}

Kata kunci: Media interaktif, aktivitas dan hasil belajar siswa

\section{PENDAHULUAN}

Keberhasilan peningkatan mutu pendidikan, tentunya tidak terlepas dari proses pendidikan yang terkait dengan kegiatan belajar mengajar di kelas. Selama kegiatan belajar mengajar sangat dibutuhkan adanya interaksi antara guru dan siswa, agar siswa dapat menyerap materi pelajaran dengan optimal. Guru memegang peran penting dalam mengarahkan siswa mencapai hasil belajar yang maksimal. Salah satu kemampuan yang diharapkan dikuasai oleh guru adalah bagaimana mengajar dengan baik. Usaha yang dapat dilakukan oleh guru adalah penggunaan media dalam proses pembelajaran. SMA Negeri 1 Wonomulyo adalah sekolah yang telah menerapkan KTSP. Akan tetapi, penerapan media pembelajaran yang sesuai dengan kurikulum tingkat satuan pendidikan belum sepenuhnya terlaksana. Berdasarkan observasi yang telah dilakukan di sekolah tersebut terlihat bahwa guru kurang memanfaatkan media sebagai 
JURNAL SAINTIFIK VOL.3 NO.1, JANUARI 2017

wahana dalam menyalurkan informasi pendukung dari kegiatan pembelajaran. Pembelajaran ini dirasakan masih terdapat kekurangan, baik dalam proses pembelajaran maupun hasil belajarnya. Selain itu, pembelajaran seperti ini masih berpusat pada guru dan belum dapat melayani peserta didik sesuai dengan kebutuhan masing-masing.

Pembelajaran berbasis ICT memiliki berbagai macam bentuk desain salah satunya dalam bentuk powerpoint dan soal flash. Pemanfaatan media pembelajaran dengan memanfaatkan program aplikasi Microsof Powerpoint dilakukan dengan mengemas materi ajar secara menarik, singkat, padat dan efektif. Powerpoint memiliki fasilitas custom animation yang sangat lengkap. Dengan fasilitas ini presentasi dapat menjadi lebih 'hidup', menarik dan interaktif. Selanjutnya siswa akan diberikan soal-soal dalam bentuk flash yang menampilkan picture, dan gambar animasi.

Memberdayakan teknologi komunikasi dan informasi di sekolah dengan mengemas bahan ajar dalam bentuk media ICT dapat meningkatkan kualitas pendidikan. Penggunaan ICT sebagai media belajar dianggap perlu dilakukan melihat dari berbagai aspek. Materi pembelajaran akan menjadi mudah terpahami karena adanya visualisasi, simulasi, interaktif, dan multimedia sehingga menimbulkan kekuatan Hypertext dibanding dengan buku. ICT memudahkan peserta didik untuk memilih, mensintesa dan mengolaborasi serta mengakomodasi siswa yang lamban belajar, meningkatkan retensi atau daya ingat siswa, mengatasi keterbatasan ruang, waktu dan tenaga. Secara relevan ICT dapat menimbulkan gairah belajar dan memungkinkan siswa belajar secara mandiri, sesuai bakat, kemampuan visual, dan auditori sehingga penyampaian pesan pembelajaran menjadi lebih terstandar, menarik, dan interaktif dalam menerapkan teori belajar. Menurut penelitian yang dilakukan oleh Ratmiana dengan penggunaan media interaktif berbasis ICT ternyata aktivitas dan hasil belajar siswa kelas X SMA negeri 3 Sungguminasa mengalami peningkatan. " Penelitian De Porter mengungkapkan manusia dapat menyerap suatu materi sebanyak 70\% dari apa yang dikerjakan, 50\% dari apa yang didengar dan dilihat (audio visual), sedangkan dari yang dilihatnya hanya $30 \%$, dari yang didengarnya hanya $20 \%$, dan dari yang dibaca hanya 10\%". Hasil penelitian di USA (Amerika Serikat): proses belajar mengajar yang dibantu alat peraga meningkatkan efesiensi 47\%, dibantu ICT meningkatkan efesiensi 93\% (Ketut dan Adhi, 2007).

\section{METODE PENELITIAN}

Penelitian ini dilaksanakan di semester 2 yang berlangsung mulai bulan 3 sampai dengan bulan 4 tahun ajaran 2009/2010, yang berlokasi di SMA Negeri 1 Wonomulyo. Subjek penelitian

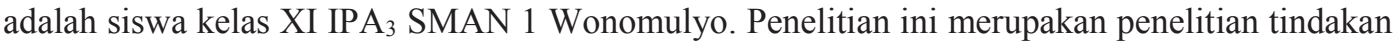
kelas (Classroom Action Research) yang terdiri atas dua siklus. Masing-masing siklus terdiri atas tahap perencanaan tindakan, tahap pelaksanaan, tahap observasi dan evaluasi, serta tahap refleksi. Pelaksanaan penelitian ini terdiri atas 3 kali pertemuan. Setiap pertemuan guru melakukan langkah-langkah pembelajaran sesuai dengan pembelajaran langsung dengan menggunakan media interaktif. Pengumpulan data yang dilakukan dalam penelitian tindakan kelas ini adalah data tentang aktivitas, sikap dan hasil belajar siswa. Data tentang aktivitas siswa selama tindakan penelitian diambil dengan menggunakan lembar observasi, data tentang sikap siswa terhadap penggunaan media interaktif yang dilakukan oleh guru selama pembelajaran berlangsung diperoleh dengan cara mengedarkan angket dan data tentang hasil belajar diambil dari nilai tes hasil belajar siswa. 


\section{HASIL DAN PEMBAHASAN}

\subsection{Hasil Penelitian}

\section{a. Aktivitas siswa}

Data hasil observasi aktivitas siswa kelas XI IPA 3 SMA Negeri 1 Wonomulyo pada siklus I dan siklus II selama proses pembelajaran melalui penggunaan media interaktif berbasis ICT yang diperoleh dengan menggunakan lembar observasi dapat dilihat pada tabel berikut ini.

Tabel 1 Distribusi dan Persentase aktivitas siswa selama proses pembelajaran dengan menggunakan media interaktif berbasis $I C T$.

\begin{tabular}{|l|l|c|c|c|c|}
\hline \multirow{2}{*}{ No } & \multicolumn{2}{|c|}{ Komponen aktivitas } & \multicolumn{4}{|c|}{ Siklus } \\
\cline { 3 - 6 } & & \multicolumn{2}{|c|}{ I } & \multicolumn{2}{|c|}{ II } \\
\cline { 3 - 6 } & $\sum \mathbf{S}$ & $\mathbf{\%}$ & $\sum \mathbf{S}$ & $\mathbf{\%}$ \\
\hline 1. & $\begin{array}{l}\text { Mengamati media interaktif berbasis } \\
I C T\end{array}$ & 22 & 81,48 & 27 & 100,00 \\
\hline 2. & Menyimak penjelasan guru & 17 & 62,96 & 24 & 88,89 \\
\hline 3. & Mencatat penjelasan guru & 19 & 70,37 & 26 & 96,30 \\
\hline 4. & Mengerjakan soal berbasis flash & 13 & 48,15 & 26 & 96,30 \\
\hline 5. & Aktif menjawab pertanyaan & 10 & 37,04 & 15 & 55,56 \\
\hline
\end{tabular}

Tabel 2 Distribusi, jumlah siswa, persentase dan kategori aktivitas belajar biologi siswa dengan menggunakan media pembelajaran berbasis ICT pada siklus I dan siklus II

\begin{tabular}{|c|c|c|c|c|c|}
\hline \multirow{2}{*}{ Interval Nilai } & \multirow{2}{*}{ Kategori } & \multicolumn{2}{|c|}{ Jumlah Siswa } & \multicolumn{2}{c|}{ Persentase (\%) } \\
\cline { 3 - 6 } & & Siklus I & $\begin{array}{c}\text { Siklus } \\
\text { II }\end{array}$ & Siklus I & Siklus II \\
\hline$\geq 15,50$ & Sangat aktif & 0 & 6 & 0,00 & 22,22 \\
\hline $12,50-15,25$ & Aktif & 8 & 7 & 29,63 & 25,93 \\
\hline $9,50-12,25$ & Cukup aktif & 6 & 13 & 22,22 & 48,15 \\
\hline $6,50-9,25$ & Tidak aktif & 13 & 1 & 48,15 & 3,70 \\
\hline
\end{tabular}

b. Hasil belajar

Tabel 3 Distribusi, frekuensi, persentase dan kategori hasil belajar biologi dengan menggunakan media ineteraktif berbasis ICT pada siklus I dan siklus II

\begin{tabular}{|c|c|c|c|c|c|}
\hline \multirow{2}{*}{ Interval Nilai } & \multirow{2}{*}{ Kategori } & \multicolumn{2}{|c|}{ Jumlah Siswa (JS) } & \multicolumn{2}{c|}{ Persentase (\%) } \\
\cline { 3 - 6 } & & Siklus I & Siklus II & Siklus I & Siklus II \\
\hline $80-100$ & Baik Sekali & 0 & 8 & 0,00 & 29,63 \\
\hline $66-79$ & Baik & 17 & 18 & 62,96 & 66,67 \\
\hline $56-65$ & Cukup & 9 & 1 & 33,33 & 3,70 \\
\hline $40-55$ & Kurang & 1 & 0 & 3,70 & 0,00 \\
\hline
\end{tabular}




\section{JURNAL SAINTIFIK VOL.3 NO.1, JANUARI 2017}

\begin{tabular}{|c|c|c|c|c|c|}
\hline $30-39$ & Gagal & 0 & 0 & 0,00 & 0,00 \\
\hline \multicolumn{2}{|c|}{ Jumlah } & 27 & 27 & 100 & 100 \\
\hline
\end{tabular}

Mengenai ketuntasan belajar biologi siswa kelas XI IPA 3 SMA Negeri 1 Wonomulyo yang diajar dengan menggunkan media pemebelajaran berbasis $I C T$, pada siklus I, siswa yang tuntas belajarnya yaitu $19(70,37 \%)$ orang siswa, sedangakan pada siklus II, siswa yang tuntas belajarnya adalah $26(96,30 \%)$ orang siswa.

\section{c. Sikap Siswa}

Tabel 5 Distribusi, jumlah siswa, persentase dan kategori hasil sikap siswa terhadap media interaktif berbasis $I C T$

\begin{tabular}{|c|c|c|c|}
\hline Interval & Kategori & Jumlah siswa & Persentase (\%) \\
\hline$\geq 44,50$ & Sangat setuju & 3 & 11,11 \\
\hline $41,91-44,24$ & Setuju & 11 & 40,74 \\
\hline $38,58-40,91$ & Tidak berpendapat & 7 & 25,93 \\
\hline $35,25-37,58$ & Tidak setuju & 3 & 11,11 \\
\hline$<35,25$ & Sangat tidak setuju & 3 & 11,11 \\
\hline
\end{tabular}

\section{d. Hubungan antara aktivitas belajar dengan hasil belajar}

1) Regresi

Tabel 6 Data hasil analisis regresi antara aktivitas belajar dengan hasil belajar siswa

\begin{tabular}{|l|l|l|}
\hline \multicolumn{2}{|l|}{ Komponen Regresi } & Nilai \\
\hline \multirow{4}{*}{$\begin{array}{l}\text { Aktivitas belajar dengan hasil } \\
\text { belajar siswa }\end{array}$} & $\mathrm{F}$ & 51,66 \\
\cline { 2 - 3 } & $\mathrm{t}$ & 17,53 \\
\cline { 2 - 3 } & Sig. & 0,00 \\
\cline { 2 - 3 } & Constant & 51,357 \\
\cline { 2 - 3 } & $\mathrm{R}$ & 0,821 \\
\cline { 2 - 3 } & $\mathrm{R}$ square & 0,674 \\
\cline { 2 - 3 } & $\mathrm{B}$ & 1,822 \\
\hline
\end{tabular}

\section{2) Korelasi}

Hubungan aktivitas belajar dengan hasil belajar dapat diketahui melalui hasil analisis $\mathrm{R}$ (korelasi). Berdasarkan hasil analisis diperoleh nilai sebesar 0,821 dengan $\alpha=0,05$. Nilai tersebut menjelaskan bahwa aktivitas belajar siswa berpengaruh positif terhadap hasil belajar siswa, untuk mengetahui apakah koefisien korelasi r yang diperoleh signifikan atau tidak, dilakukan pengujian dengan menggunakan analisis uji-t. Hasil analisis uji-t diperoleh nilai t hitung sebesar 17,53 dengan tingkat signifikansi 0,000 yang kurang dari $\alpha=0.05$. Ini menunjukkan bahwa koefisien aktivitas belajar siswa terhadap hasil belajar signifikan.

\section{3) Indeks determinasi}

Hasil analisis indeks determinasi yang telah di lakukan, diperoleh nilai $\mathrm{R}^{2}=0,674$. Nilai indeks determinasi yang diperoleh memberikan pengertian bahwa kontribusi aktivitas belajar terhadap hasil belajar siswa adalah $67,4 \%$, dan 32,6 \% dijelaskan oleh variabel lain yang tidak masuk dalam model analisis ini. Hasil analisis regresi, $\mathrm{R}$, dan $\mathrm{R}^{2}$ menunjukkan bahwa terdapat hubungan positif antara aktivitas belajar dengan hasil belajar siswa. 
JURNAL SAINTIFIK VOL 3 NO.1, JANUARI 2017

e. Hubungan antara sikap terhadap media pembelajaran berbasis ICT dengan hasil belajar

1) Regresi

Tabel 9 Data hasil analisis regresi antara sikap dengan hasil belajar siswa

\begin{tabular}{|c|c|c|}
\hline \multicolumn{1}{|c|}{ Komponen Regresi } & Nilai & \\
\hline \multirow{5}{*}{ Sikap dengan hasil belajar siswa } & $\mathrm{F}$ & 104,23 \\
\cline { 2 - 3 } & $\mathrm{t}$ & 10,21 \\
\cline { 2 - 3 } & $\mathrm{Sig}$ & 0,00 \\
\cline { 2 - 3 } & Constant & 7,835 \\
\cline { 2 - 3 } & $\mathrm{R}$ & 0,898 \\
\cline { 2 - 3 } & $\mathrm{R}$ squard & 0,807 \\
\cline { 2 - 3 } & $\mathrm{B}$ & 1,591 \\
\hline
\end{tabular}

2) Korelasi

Hubungan sikap terhadap media interaktif dengan hasil belajar dapat diketahui melalui hasil analisis R (korelasi). Hasil analisis yang telah dilakukan, diperoleh nilai sebesar 0,898 dengan $\alpha=0,05$. Nilai tersebut menjelaskan bahwa aktivitas belajar siswa berpengaruh positif terhadap hasil belajar siswa, untuk mengetahui apakah koefisien korelasi $r$ yang diperoleh signifikan atau tidak, dilakukan pengujian dengan menggunakan analisis uji-t. Hasil analisis uji$\mathrm{t}$ diperoleh nilai t hitung sebesar 10,21 dengan tingkat signifikansi 0,00 yang kurang dari $\alpha=$ 0.05. Ini menunjukkan bahwa koefisien aktivitas belajar siswa terhadap hasil belajar signifikan. 3) Indeks determinasi

Hasil analisis indeks determinasi yang telah dilakukan, diperoleh nilai $\mathrm{R}^{2}=0,807$. Nilai indeks determinasi yang diperoleh memberikan pengertian bahwa kontribusi aktivitas belajar terhadap hasil belajar siswa adalah 80,7\%, dan 19,3\% dijelaskan oleh variabel lain yang tidak masuk dalam model analisis ini. Hasil analisis regresi, $\mathrm{R}$, dan $\mathrm{R}^{2}$ menunjukkan bahwa terdapat hubungan positif antara sikap terhadap media pembelajaran berbasis ICT dengan hasil belajar siswa.

\section{f. Refleksi}

\section{1) Refleksi siklus I}

Penerapan media pembelajaran berbasis ICT pada siklus I telah menunjukkan adanya peningkatan aktivitas belajar dari pertemuan pertama ke pertemuan kedua. Kenyataannya, pada akhir siklus I masih ditemukan beberapa masalah yang selanjutnya dijadikan sebagai refleksi untuk perbaikan tindakan pada siklus II. Adapun permasalahan yang ditemukan selama proses pembelajaran adalah sebagai berikut:

a. Dalam ruangan posisi kursi tidak teratur sehingga ada beberapa siswa yang tidak jelas melihat media yang ditampilkan oleh guru.

b. Masih ada beberapa siswa yang masih melakukan hal-hal yang dapat menggangu proses pembelajaran seperti berbicara dengan temannya, main HP, tidak mendengarkan penjelasan guru, dan berkeliaran di dalam kelas atau keluar masuk kelas.

c. Masih ada beberapa siswa yang takut ataupun malu-malu untuk menjawab pertanyaan, bertanya maupun mempresentasikan hasil kerjanya. 
JURNAL SAINTIFIK VOL.3 NO.1, JANUARI 2017

d. Masih ada beberapa siswa yang tidak mengerjakan soal berbasis flash, karena guru tidak memberitahu bahwa soal tersebut soal berbasis flash, sehingga siswa menganggap soal yang di berikan adalah soal seperti soal biasa.

Menyikapi berbagai masalah yang terjadi selama siklus I baik dari pertemuan pertama maupun pertemuan kedua, maka perbaikan yang dilaksanakan pada siklus II lebih ditekankan pada pengelolaan kelas, antara lain:

a. Mengatur posisi kursi yang ada dalam ruangan

b. Menekankan ke siswa bahwa dalam ruangan HP di non aktifkan, memisahkan siswa yang bercerita dan yang pasif, sehingga tidak ada lagi siswa yang saling menggangu dan yang terakhir memberikan motivasi kepada siswa agar lebih disipin dalam belajar.

c. Meningkatkan keberanian siswa untuk menjawab pertanyaan, bertanya maupun mempresentasikan hasil kerjanya dengan cara menyampaikan kepada siswa bahwa disini saatnya kalian latihan untuk tampil di depan orang banyak tanpa perlu merasa takut ataupun malu disamping itu memberikan peluang atau kesempatan siswa yang lain untuk

d. Menyampaikan nilai tes hasil belajar siklus I pada kegiatan awal pertemuan pertama siklus II dengan harapan, hasil tersebut menjadi motivasi bagi siswa untuk lebih giat belajar dan lebih berperan aktif dalam proses pembelajaran untuk mencapai hasil belajar yang maksimal.

e. Menyampaikan ke siswa bahwa soal yang di kerjakan adalah soal berbasis flash dan meminta siswa mencocokkan jawabannya

Hasil pengkategorian nilai tes hasil belajar biologi siswa pada siklus I menunjukkan bahwa siswa yang mendapat nilai pada kategori baik sekali 0 siswa $(0.00 \%)$ dan siswa pada kategori baik yakni 17 (62,96\%), pada kategori cukup terdapat 9 siswa $(33,33 \%)$, dan pada kategori kurang 1 siswa $(3,70 \%)$. Berdasarkan kriteria ketuntasan minimal yang digunakan di SMA Negeri I Sinjai Utara terlihat bahwa hanya 19 siswa (70,37\%) yang tuntas dari 27 siswa. Upaya dalam meningkatkan suatu hasil belajar maka keaktifan siswa dalam proses belajar mengajar harus ditingkatkan sehingga penelitian ini dilanjutkan ke siklus II.

\section{2) Refleksi siklus II}

Pelaksanaan tindakan siklus II sebagai perbaikan dari pelaksanaan siklus I memberikan dampak yang positif terhadap aktivitas siswa, secara umum hasilnya semakin sesuai yang diharapkan, dimana pada siklus II aktivitas siswa lebih meningkat. Nilai hasil belajar biologi siswa pada siklus II juga telah mengalami peningkatan dari siklus I. Peningkatan ini ditunjukkan oleh meningkatnya nilai rata-rata siswa dari siklus I ke siklus II, dari 68,81 menjadi 74,93 dan persentase siswa yang tuntas pada siklus II juga meningkat dari 70,37\% atau 19 siswa dari 27 siswa menjadi 96,30\% atau 26 orang dari 27 siswa. Nilai ini memenuhi indikator kinerja yang ingin dicapai yakni ketuntasan nilai minimal 75\%, sehingga penelitian ini dikatakan berhasil dan tidak perlu dilanjutkan ke siklus berikutnya. Siswa yang belum memenuhi standar ketuntasan secara individu diberikan remedial oleh gurunya.

Melihat pemaparan di atas, maka tampak bahwa sebagian besar kendala yang dihadapi pada siklus I dapat teratasi meskipun masih terjadi pada siklus II, sehingga dengan demikian dapat dinyatakan bahwa penggunaan media interaktif dapat memberikan konstribusi positif terhadap peningkatan aktivitas, sikap, dan hasil belajar biologi siswa kelas XI IPA ${ }_{3}$ SMA Negeri 1 Sinjai Utara. 


\subsection{Pembahasan}

Hasil analisis data yang diuraikan pada Tabel 1 mengenai aktivitas belajar siswa kelas XI $\mathrm{IPA}_{3}$ SMA Negeri 1 Sinjai Utara selama proses pembelajaran memperlihatkan adanya peningkatan dari siklus I ke siklus II. Ada 5 komponen aktivitas yang diamati, dan semua aktivitas siswa tersebut mengalami peningkatan. Peningkatan aktivitas belajar siswa kelas XI IPA 3 SMA Negeri 1 Wonomulyo dapat dilihat pada tabel 1 dimana setelah penerapan media pembelajran berbasis $I C T$, aktivitas belajar siswa meningkat dari siklus I ke siklus II. Aktivitas itu meliputi siswa yang aktif dalam menjawab pertanyaan dari guru, yaitu dengan persentase 37,04\% di siklus I naik menjadi 55,56\% pada siklus II. Siswa yang kurang aktif dalam menjawab pertanyaan dari guru pada siklus I disebabkan karena siswa pada umumnya masih malu-malu dan takut mengemukakan jawaban atas pertanyaan yang diberikan oleh guru mengingat awal pertemuan dimana guru dan siswa belum saling mengenal karakter satu sama lain, sedangkan pada siklus II beberapa siswa sudah mulai memberanikan diri menjawab pertanyaan dari guru, artinya siswa telah memiliki kemampuan untuk berinteraksi. Seorang pakar pendidikan, Trinandita dalam Shvoong (2010), menyatakan bahwa 'hal yang paling mendasar yang dituntut dalam proses pembelajaran adalah keaktifan siswa'. Keaktifan siswa dalam proses pembelajaran akan menyebabkan interaksi yang tinggi antara guru dengan siswa ataupun dengan siswa itu sendiri. Interaksi ini akan mengakibatkan suasana kelas menjadi segar dan kondusif, dimana masing masing siswa dapat melibatkan kemampuannya semaksimal mungkin. Aktivitas yang timbul dari siswa akan mengakibatkan pula terbentuknya pengetahuan dan keterampilan yang akan mengarah pada peningkatan prestasi.

Penggunaan media interaktif membuat siswa terlihat bersemangat dan sangat antusias mengamati materi, gambar dan animasi yang disajikan dalam power point, di samping itu siswa senang mengerjakan soal berbasis flash, sehingga pembelajaran tidak hanya berpusat pada guru melainkan pada siswa itu sendiri. Meningkatnya aktivitas belajar siswa yang diperoleh seiring dengan peningkatan hasil belajar siswa yang meningkat dari nilai rata-rata dari 68,81 pada siklus I menjadi 74,93 pada siklus II. Nilai siswa dikategorikan kedalam kategori sangat baik, baik, cukup dan kurang.. Nilai siswa diperoleh melalui tes evaluasi yang dibuat berdasarkan indikator pembelajaran yang akan dicapai. Semakin tinggi nilai hasil tes yang mereka porelah, menandakan bahwa semakin banyak indikator pembelajaran yang mereka capai (tuntas).

Sikap siswa terhadap penggunaan media interaktif dapat dilihat pada tabel 5 (halaman 5), dari 27 siswa memberikan penilaian sikap belajarnya terhadap media interaktif, terdapat 3 $(11,11 \%)$ siswa yang sikap belajarnya terhadap media interaktif berada pada kategori sangat setuju, $11(40,74 \%)$ siswa yang sikap belajarnya terhadap media interaktif berada pada kategori setuju, $7(25,93 \%)$ siswa yang sikap belajarnya terhadap media interaktif berada pada kategori tidak berpendapat, $3(11,11 \%)$ siswa yang sikap belajarnya terhadap media interaktif berada pada kategori tidak setuju dan $3(11,11 \%)$ siswa yang sikap belajarnya terhadap media interaktif berada pada kategori sangat tidak setuju. Berdasarkan pernyataan tersebut dan data tabel 5 , dapat dikatakan rata-rata siswa setuju adanya penggunaan media interaktif berbasis $I C T$ dalam proses pembelajaran

Menurut penelitian yang dilakukan A. Ratmiana, diperoleh hasil belajar siswa meningkat setelah media interaktif berbasis ICT diterapkan. Peningkatan nilai ketuntasan hasil belajar siswa yang diperoleh pada siklus I adalah 20 orang $(62,5 \%)$ meningkat menjadi 29 orang $(90,6 \%)$ pada siklus II mengalami peningkatan sebanyak $28,1 \%$. Hasil peningkatan ketuntasan belajar siswa yang diperoleh Ratmiana, ternyata tidak jauh beda dengan peningkatan ketuntasan belajar siswa 


\section{JURNAL SAINTIFIK VOL.3 NO.1, JANUARI 2017}

yang diperoleh oleh peneliti di kelas XI IPA 3 SMA Negeri 1 Sinjai Utara. Peningkatan nilai ketuntasan hasil belajar yang diperoleh yaitu 70,37\% atau 19 siswa dari 27 siswa pada siklus I menjadi $96,30 \%$ atau 26 orang dari 27 siswa pada siklus II dan mengalami peningktan sebanyak $25,93 \%$. Hasil yang diperoleh ini membuktikan bahwa pembelajaran dengan menggunakan media interaktif dapat meningkatkan aktivitas dan hasil belajar siswa.

\section{KESIMPULAN}

Berdasarkan hasil penelitian, analisis data, dan pembahasan, maka dapat disimpulkan:

1. Penggunaan mediainteraktif berbasis $I C T$ dapat meningkatkan aktivitas dan hasil belajar biologi siswa kelas XI IPA 3 SMA Negeri 1 Sinjai Utara.

2. Aktivitas dengan hasil belajar dan sikap dengan hasil belajar memiliki korelasi, artinya ketika aktivitas dan sikap seorang siswa semakin baik, maka hasil belajarnya semakin baik pula.

\section{DAFTAR PUSTAKA}

Ketut, D dan Adhie. 2007. Membangun Media Belajar Berbasis ICT. Http://bp3.blogger.com. Diakses tanggal 4 Januari 2010.

Ratmiana, A. 2009. Peningkatan Hasil Belajar Biologi Siswa Kelas X Melalui Penggunaan Media Interaktif Berbasis Information, Communication, and Technology (ICT) di SMA Negeri 3 Sungguminasa. Skripsi Sarjana Pendidikan Jurusan Biologi FMIPA UNM.

Shvoong. 2010. Aktivitas Belajar. http://id.shvoong.com. Diakases pada tanggal 4 Januari 2010. 